\title{
MEMBERIKAN YANG TERBAIK MELALUI MEMBANGUN SEBUAH KEPERCAYAAN DI DALAM PELAYANAN
}

\author{
Amos Winarto Oei
}

\begin{abstract}
ABSTRAKSI
Kepemimpinan pastoral tidaklah harus dikaitkan dengan sebuah perubahan atau pembaharuan. Artikel ini ditulis untuk menunjukkan bahwa salah satu cara melakukan kepemimpinan pastoral adalah melalui membangun kepercayaan jemaat atau gereja kepada hamba Tuhannya. Dengan kata lain, artikel ini tidak akan berfokus pada "apa" dan "mengapa" dari kepemimpinan pastoral melainkan pada "bagaimana" dari kepemimpinan pastoral.
\end{abstract}

Kata Kunci: Kepemimpinan pastoral, Perubahan, Pembaharuan

Mengapa seorang pendeta atau penginjil harus memimpin? Banyak dari kita mengetahui jawaban dari pertanyaan itu. ${ }^{1}$ Apa artinya bagi seorang hamba Tuhan full-time untuk memimpin? Apakah dasar-dasar Alkitab untuk kepemimpinan pastoral? Banyak dari kita juga mengetahui jawaban terhadap pertanyaan-pertanyaan itu. $^{2}$ "Mengapa" dan "Apa" dari kepemimpinan pastoral adalah penting. Namun artikel ini tidak akan lagi menjawab pertanyaan tersebut melainkan akan berfokus pada pertanyaan ketiga terkait dengan kepemimpinan pastoral, yaitu "Bagaimana" dari kepemimpinan pastoral.

${ }^{1}$ Lihat, misalnya, David Rohrer, The Sacred Wilderness of Pastoral Ministry: Preparing A People for the Presence of the Lord (Downers Grove: IVP Books, 2012) dan Pal David Tripp, Dangerous Calling: Confronting the Unique Challenges of Pastoral Ministry (Wheaton: Crossway/Good News Publishers, 2012).

2 Lihat juga dasar-dasar Alkitab kepemimpinan pastoral misalnya di Thomas C. Oden, Pastoral Theology: Essential of Ministry (San Fransisco: Harper San Fransisco, 1983) dan John McArthur, Pastoral Ministry: How To Shepherd Biblically (Nashville: Thomas Nelson, 2005) 
Seorang guru yang baik mengajar bukan karena dia mempunyai sesuatu untuk dikatakan. Seorang guru yang baik mengajar karena dia harus mengatakan sesuatu. Demikian juga, seorang pemimpin yang baik memimpin bukan karena dia mempunyai sesuatu untuk dipimpin. Seorang pemimpin yang baik memimpin karena dia memang harus memimpin. Paulus pernah mengatakan bahwa upahnya adalah memberitakan Injil (1 Korintus 9:18). Dalam kaitan dengan kepemimpinan pastoral, ayat tersebut dapat dipahami bermakna bahwa seorang pemimpin yang baik adalah juga giat di dalam kepemimpinannya. Banyak gereja akan diberkati melalui pemimpin yang giat, bukan yang suam-suam kuku. Yesus sendiri menegur gereja di Laodikia supaya tidak suam-suam kuku! (Wahyu 3:16). Walaupun demikian, "giat" saja tidak cukup untuk membuat seseorang menjadi pemimpin yang baik. Misalnya, pemimpin yang "giat" untuk terus melakukan perubahan di dalam organisasi bisa jadi malah tidak membangun melainkan merusak organisasi yang dipimpinnya.

Saya akan memulai artikel ini dengan sebuah soal antara kepemimpinan pastoral dan perubahan atau pembaharuan. Sebuah kisah akan menggambarkan soal tersebut. Mengapa saya memakai kisah ini? Karena kisah ini cenderung dialami oleh para pemimpin muda yang baru memulai masa kepemimpinan mereka. Chuck Fuller mengisahkannya demikian: ${ }^{3}$

Saya berusaha untuk bersukacita bersama rekan saya terkait dengan usaha yang dia kisahkan melalui telepon. Dari hari pertamanya sebagai seorang gembala sidang di sebuah gereja cukup besar di kota kecil dia telah suka pada sebuah model pelayanan yang baru - sesuatu yang dia yakini bisa membawa gereja itu semakin maju - sesuatu yang akan melenyapkan adat kebiasaan yang sudah basi. Dia punya sebuah rencana! Ketika dituangkan secara tertulis, rencana itu tebalnya sekitar $1 \mathrm{~cm}$ - sebuah manual menjelaskan bagaimana gerejanya seharusnya melakukan pelayanan. Manual itu mendefinisikan tanggung jawab para pegawai gereja, mengorganisasi ulang setiap komite menjadi tim

${ }^{3}$ Kisah lengkapnya dapat ditemukan di Chuck Fuller, Pastoral Perceptivity: An Essential Tool for Ministry, http://www.ministryu.org/pastoral-perceptivity-anessential-tool-for-ministry/, diakses 6 Juni 2013. 
pelayanan, menyediakan garis batas yang jelas soal jalur komunikasi dan pengambilan keputusan, dan menyatukan seluruh struktur gereja yang ada di bawah sebuah pernyataan visi yang padat dan ringkas. Manual strategi pelayanan ini menunjukkan kecemerlangan talenta administrasi sang gembala sidang tersebut!

Sayangnya, dia gagal melihat bahwa rencananya untuk sukses itu justru membuka jalan kegagalannya di gereja itu. Di dalam teleponnya dia berkata dengan penuh kegembiraan, "Berhasil! Rapat kemarin menyetujui dengan nilai voting 67\%, jadi manual ini bisa segera ditindaklanjuti." Suaranya yang antusias menimbulkan kekuatiran di dalam hati saya. Saya kuatir bahwa dia tidak memenangkan sebuah pertempuran, melainkan malah memulainya. Dan memang benar, perlawanan terhadap usahanya melakukan perubahan dan bahkan tuduhan-tuduhan terhadapnya berkembang dengan pesat dalam waktu tiga tahun, sampai karena tertekan dan kebingungan, rekan saya itu mengundurkan diri dari pelayanannya di gereja tersebut.

Apa yang bisa kita pelajari dari kisah di atas? Fuller percaya bahwa masalahnya bukanlah pada rencana besar rekannya bagi gereja itu. Masalahnya bukanlah juga para anggota dan pemimpin jemaat di gereja itu. Masalahnya adalah kurangnya pengertian (perseptivitas). Rekannya itu gagal untuk mengerti bahwa dia tidak sedang berhadapan dengan model pelayanan yang telah basi, melainkan sebuah budaya yang telah berakar dalam - yaitu, sebuah cara melakukan sesuatu yang jemaat di gereja itu, di bawah beberapa gembala sidang sebelumnya, telah tumbuh kembangkan selama beberapa dekade - bahkan dari generasi ke generasi! Gembala sidang yang baru itu tidak hanya berusaha untuk mengubah bagaimana mereka melakukan pelayanan di dalam gereja melainkan siapa atau jati diri mereka. Dia gagal untuk mengerti bahwa syarat utama untuk suatu perubahan yang radikal tersebut adalah sebuah kepercayaan radikal - sebuah level kepercayaan dari jemaat yang tidak mudah didapat dan dikembangkan di dalam dua tahun hamba Tuhan baru itu menjadi seorang gembala sidang. Akhirnya, gembala sidang itu gagal untuk mengerti bahwa memenangkan voting di dalam sebuah rapat belum tentu merupakan sebuah kemenangan. $67 \%$ suara itu hanyalah 
menyatakan bahwa ada perbedaan pendapat cukup tajam di dalam gereja itu dan bahkan jumlah voting tersebut malah mungkin mengindikasikan adanya konflik-konflik lebih lanjut yang bisa membawa kepada perpecahan gereja. Seringkali yang dibutuhkan adalah bukan hasil voting yang cukup, yaitu asal bisa lolos disetujui, melainkan justru dibutuhkan hasil voting lebih dari $90 \%$ lah yang membuat pembaharuan atau perubahan itu lebih mudah diterima dan diimplementasikan.

Kita memperoleh satu pelajaran berharga soal kepemimpinan pastoral dari cerita di atas. Kepemimpinan pastoral tidak selalu berarti bahwa memimpin itu adalah melakukan suatu pembaharuan atau perubahan! John Maxwell setuju dengan observasi di atas. Di dalam interviewnya bersama majalah Preaching edisi Juli-Agustus 2004, dia berbicara tentang peran pembaharuan atau perubahan di dalam kepemimpinan pastoral. Dia berkata:

Tiga puluh tahun lalu ketika saya mengajarkan kepemimpinan, saya mungkin sudah salah dalam mengatakan bahwa para pemimpin itu seperti sebuah pembaharuan dan hadir untuk membuka jalan untuk perubahan dan bahwa para pengikut tidak menyukai perubahan dan merupakan penghambat dan penghalang dari perubahan. Saya tidak lagi berpikir demikian. Saya berpikir bahwa kebanyakan pemimpin tidak menyukai perubahan seperti para pengikutnya, kecuali perubahan itu adalah ide yang muncul dari diri para pemimpin itu sendiri. Sesungguhnya, saya sekarang berpikir ketika perubahan itu tidak terjadi di dalam sebuah organisasi atau gereja, hal tersebut bukanlah karena para pengikut menolak perubahan itu melainkan karena para pemimpin menolak perubahan. Para pengikut pada umumnya tidak mempunyai pengaruh dan sering ikut arus. Karena itulah mereka disebut para pengikut. Karena itu ketika perubahan tidak terjadi, hampir itu selalu akibat sabotase. Ada seorang pemimpin yang melakukan sabotase, bukanlah para pengikut. Seorang gembala sidang tidaklah perlu kuatir dengan jemaatnya melainkan harus jujur dengan dirinya sendiri. Ketika gereja-gereja tidak berubah, itu bukanlah masalah para pengikutnya; seringkali justru masalah dari pemimpinnya.

Walaupun saya sudah mengatakan demikian, saya perlu berhati-hati dengan mengatakan bahwa saya tidak 
menganjurkan atau mengagumi perubahan itu sendiri. Saya mengetahui ada banyak orang yang mengingini perubahan semata-mata karena mereka resah, gelisah dan tidak tenang dengan tidak adanya perubahan. Kalau itu terjadi, saya tidak yakin bahwa perubahan yang terjadi adalah sebuah perubahan yang baik. Saya berpikir pertumbuhan - yaitu, pertumbuhan yang sejati dan sah - mengharuskan adanya perubahan. Kita tidak dapat bertumbuh dalam suatu masa tertentu tanpa membuat perubahan-perubahan besar. Jadi saya meyakini bahwa pertumbuhan itu berarti perubahan. Bukan sebaliknya, yaitu perubahan berarti pertumbuhan.

Jika seseorang berkata, "Lihat, saya sedang melakukan beberapa perubahan," maka saya akan mengatakan, "Itu tidaklah menjadikan sesuatu lebih baik." Saya mengenal orang-orang yang telah melakukan beberapa perubahan atau pembaharuan dan malah kondisinya menjadi lebih buruk. Karena itu janganlah kita menjunjung tinggi perubahan atau pembaharuan. Mari kita menjunjung tinggi pertumbuhan. Jika pertumbuhan terjadi, seseorang akan berubah; apa yang saya temukan adalah ketika pertumbuhan terjadi, perubahan akan diterima dengan lebih positif. Saya menantang bukan untuk mengubah gereja atau hamba Tuhan; saya menantang untuk menumbuhkan gereja dan menumbuhkan hamba Tuhan. Jika saya sungguh dapat membawa mereka di dalam sebuah pola pertumbuhan, mereka akan memperoleh daya gerak untuk melakukan perubahan atau pembaharuan yang mereka perlu untuk miliki.

Kita dapat berdebat dengan Maxwell mengenai siapakah sesungguhnya agen pertumbuhan itu karena Paulus pernah mengatakan bahwa "hanya Allah yang memberi pertumbuhan" (1 Korintus 3:6). Ini berimplikasi bahwa kepemimpinan pastoral seharusnya tidak berfokus pada pertumbuhan itu sendiri. Adalah tugas Allah untuk menumbuhkan gereja dan hamba-hamba Tuhan. Kepemimpinan pastoral mungkin seharusnya hanya berkaitan dengan penanaman dan penyiraman. Walaupun demikian, yang penting di sini adalah kita memahami maksud dan kerinduan hati Maxwell di atas: memimpin dengan tujuan untuk melakukan sebuah perubahan atau pembaharuan bukanlah cara yang tepat di dalam kepemimpinan pastoral. 
Sekarang, apakah cara yang lebih tepat untuk melakukan kepemimpinan pastoral? Dengan menggabungkan pelajaran dari kisah Fuller dan wawancara Maxwell di atas, kita menemukan bahwa memimpin secara pastoral memerlukan sebuah kemampuan untuk mengerti level kepercayaan yang jemaat miliki terhadap hamba Tuhannya dan kemampuan untuk mengenali cara jemaatnya akan mendengarkan dan menerima ide-ide yang dia berikan. Hershael W. York membandingkan kepercayaan jemaat terhadap hamba Tuhannya dengan sekantung kepingan kartu poker (maafkan rujukan pada permainan poker ini!) yang dimiliki oleh hamba Tuhan tersebut. ${ }^{4}$ Ketika seorang hamba Tuhan datang untuk pertama kalinya, gereja pada umumnya akan bersemangat untuk menerimanya, mempercayainya dan menunjukkan perhatian padanya. Masa ini adalah masa bulan madu dan kantung hamba Tuhan itu penuh dengan kepingan kartu poker. Namun setiap perubahan yang hamba Tuhan itu lakukan harus dibayar dengan kepingan kartu poker di dalam kantungnya. Semakin besar perubahan yang diharapkan oleh hamba Tuhan itu untuk terjadi, semakin banyak kepingan kartu poker yang dibutuhkan.

Sebagai contoh, sebuah perubahan kecil di dalam ibadah hari Minggu, seperti meletakkan warta jemaat pada akhir ibadah dan bukan setelah khotbah, mungkin tidak membuat hamba Tuhan itu membuang banyak kepingan kartu poker dari kantungnya. Tetapi jika dia ingin mengubah bentuk musik di dalam ibadah gereja itu (misalnya dari musik klasik ke musik kontemporer, dari tidak memakai band di dalam ibadah diubah menjadi menggunakan), maka lebih banyak kepingan kartu poker yang dibutuhkan. Bahkan mungkin akan membuat dia harus mengosongkan kantungnya untuk melakukan perubahan ini. Jika hamba Tuhan itu tetap bersikeras untuk melakukan perubahan itu sementara kepingan kartu poker sudah habis dalam kantungnya, maka kredibilitasnya (yaitu kepercayaan dari jemaat) akan semakin menurun dan sebagai akibatnya halangan dan hambatan akan muncul.

Seorang hamba Tuhan mengisi ulang kepingan kartu poker didalam kantungnya melalui melakukan tugas-tugas pelayanannya dengan baik. Misalnya, berkhotbah dengan tidak ruwet, rajin

\footnotetext{
4 Hershael W. York, "How to Implement and Sustain Change in A Local Church," Towers 8, vol. 13 (12 April 2010): 4.
} 
melakukan pembesukan, tidak mudah emosi di dalam menghadapi konflik, setia memberitakan Injil, dan sebagainya. Jika isteri atau suaminya memilih untuk melibatkan diri membantu pelayanan pasangannya, maka seringkali sang isteri atau suami akan memberikan lebih banyak kepingan kartu poker untuk pasangannya yang adalah hamba Tuhan itu.

Analogi kepingan kartu poker ini menunjukkan bahwa seorang hamba Tuhan yang memimpin dengan baik memiliki sebuah kemampuan untuk mengenali dua hal penting: berapa banyak keping yang dibutuhkan untuk membuat sebuah perubahan dan berapa banyak keping yang masih dia punyai. Dari sini kita belajar bahwa di dalam kepemimpinan pastoral seorang hamba Tuhan perlu mengenali saatnya dia itu dipercayai oleh jemaat untuk membuat suatu pembaharuan dan kapan waktunya dia perlu untuk berhenti melakukan perubahan dan mengisi ulang kepingan kartu poker di dalam kantungnya.

Mari kita sekarang melihat kembali sebuah kisah lain oleh Chuck Fuller. Kali ini adalah kisahnya sendiri. ${ }^{5}$

Ketika saya masih seorang hamba Tuhan pemuda-remaja, saya melayani di bawah komando seorang gembala sidang yang sangat trampil dalam soal pengertian yang dibutuhkan dalam kepemimpinan pastoral Dia berhasil memimpin sebuah jemaat kecil yang erat kekeluargaannya untuk mengalami pertumbuhan rohani. Dalam masanya sebagai seorang gembala, gerejanya memperkerjakan dua posisi staf yang baru, meluncurkan sebuah pelayanan penginjilan yang terprogram, memulai program olahraga anak-anak untuk menjangkau masyarakat sekitar, dan membangun sebuah tempat ibadah yang baru - semuanya hampir tanpa konflik sama sekali. Dia sepertinya selalu memahami dengan tepat kapan untuk mendorong adanya perubahan dan kapan untuk berhenti. Dia mengenali peperangan mana yang paling penting untuk dimenangkan, yang mana dia bisa menang, dan yang mana dia seharusnya tunda. Untuk beberapa saat

5 Chuck Fuller, Pastoral Perceptivity: An Essential Tool for Ministry, http://www.ministryu.org/pastoral-perceptivity-an-essential-tool-for-ministry/, diakses 6 Juni 2013. 
lamanya saya mengira bahwa kemampuan seperti ini adalah suatu kemampuan spesial bahkan sebuah talenta supranatural yang tidak masuk di dalam daftar talenta-talenta Perjanjian Baru!

Dalam perjalanan waktu kemudian, saya baru menyadari bahwa apa yang telah dia capai sebenarnya adalah kunci untuk memiliki pengertian dalam kepemimpinan pastoral, yaitu sebuah koneksi relasional. ${ }^{6}$ Dia mencurahkan seluruh hidupnya ke dalam jemaatnya - muncul bukan hanya di rumah sakit dan rumah duka, melainkan juga di pertandingan olahraga SMA para pemuda remajanya. Dia bisa muncul di sekolah dan di sawah. Dia pergi dimana orang-orang bekerja dan anak-anak bermain. Dia bekerja keras untuk mengingat nama-nama dan menindaklanjuti orang-orang yang baru hadir pertama kali di ibadah gerejanya. Dia juga dengan rajin menghormati tokoh-tokoh pemimpin di gerejanya, menyediakan banyak waktu dengan mereka. Dia dengan sabar mendengarkan segala pihak dalam sebuah perdebatan dan selalu menguasainya emosinya. Singkat kata, dia mengenali jemaatnya, dan melalui mengenali mereka, dia dapat mengerti mereka. Semakin dia mengerti mereka, semakin dia mampu untuk memimpin mereka dan semakin mereka percaya kepadanya. Dia memberi hormat dimana itu harus diberikan (Roma 12-13); memberitakan Injil dan berbagi hidup dengan jemaatnya (1 Tesalonika 2:8); dan dengan sabar menggembalakan kawanan domba Allah (1 Petrus 5:15). Dia sebenarnya menjalankan sebuah model pelayanan yang sudah ada di dalam Perjanjian Baru bagi kepemimpinan pastoral yang membantu perkembangan pengertiannya terhadap gereja dimana dia melayani dan Tuhan memakainya untuk menyatukan dan memberi pertumbuhan dalam gerejanya!

Koneksi relasional yang disebut dalam kisah di atas sebetulnya adalah sebuah istilah keren bagi usaha membangun sebuah kepercayaan di dalam kepemimpinan pastoral. Kisah itu menunjukkan bahwa bagi seorang hamba Tuhan untuk memiliki sebuah pengertian (perseptivitas) terhadap gereja pada dasarnya mengatakan bahwa seorang hamba Tuhan perlu membangun

\footnotetext{
${ }^{6}$ Penekanan oleh saya sendiri.
} 
sebuah kepercayaan dari jemaat untuknya. Hamba Tuhan perlu mempunyai sebuah hubungan batin dengan gerejanya. Gereja perlu mempercayai hamba Tuhannya dan demikian sebaliknya. Ini memang membutuhkan waktu. Seperti menanam dan menyiram, membangun sebuah kepercayaan gereja kepada hamba Tuhannya membutuhkan kesabaran, usaha dan tenaga dari hamba Tuhan tersebut. Kita tidak dapat membuat-buat kepercayaan dari jemaat itu. Kepercayaan itu harus muncul secara alami dari jemaat itu sendiri dan malah seringkali muncul setelah melewati berbagai tantangan dan pergumulan. Bagaikan seorang ibu melahirkan bayinya, kepercayaan itu tidak bisa dibuat-buat melainkan dilahirkan. Karena itu, jika seorang hamba Tuhan hendak memberikan yang terbaik di dalam kepemimpinan pastoralnya, maka inilah salah satu "Bagaimana" dalam kepemimpinan pastoral. Jika kepercayaan itu terbangun, maka pertumbuhan akan dimungkinkan, apakah itu di dalam diri hamba Tuhan itu sendiri atau di dalam gerejanya, atau bahkan kedua-duanya. Namun, sekali lagi, Tuhanlah yang memberi pertumbuhan. Yang seharusnya para hamba Tuhan lakukan dalam kepemimpinan pastoral untuk memberikan yang terbaik kepada Tuhan adalah membangun sebuah kepercayaan jemaat kepadanya. 